\begin{tabular}{rl|l}
$\begin{array}{c}\text { Cellular Physiology } \\
\text { and Biochemistry }\end{array}$ & Cell Physiol Biochem 2012;30:61-74 & \\
\cline { 2 - 3 } DOI: 10.1159/000339048 & $\begin{array}{l}\text { O 2012 S. Karger AG, Basel } \\
\text { www.karger.com/cpb }\end{array}$ \\
\cline { 2 - 3 } & Accepted online: June 08, 2012 02,2012 & $1015-8987 / 12 / 0301-0061 \$ 38.00 / 0$
\end{tabular}

\title{
AMP Converted from Intracellularly Transported Adenosine Upregulates p53 Expression to Induce Malignant Pleural Mesothelioma Cell Apoptosis
}

\author{
Yoshitaka Nogi1,2* Takeshi Kanno ${ }^{1 *}$ Takashi Nakano ${ }^{2,3}$ Yumiko Fujita ${ }^{1,2}$ Chiharu \\ Tabata $^{2}$ Kazuya Fukuoka ${ }^{3}$ Akinobu Gotoh ${ }^{4}$ Tomoyuki Nishizaki ${ }^{1}$ \\ ${ }^{1}$ Division of Bioinformation, Department of Physiology, Hyogo College of Medicine, Nishinomiya, \\ 2Division of Pulmonary Medicine, Department of Internal Medicine, Hyogo College of Medicine, \\ Nishinomiya, ${ }^{3}$ Cancer Center, Hyogo College of Medicine, Nishinomiya, ${ }^{4}$ Laboratory of Cell and Gene \\ Therapy, Institute for Advanced Medical Sciences, Hyogo College of Medicine, Nishinomiya, *Y. Nogi \\ and T. Kanno contributed equally to this work
}

\section{Key Words}

Adenosine $\bullet$ AMP $\bullet$ p53 $•$ Malignant pleural mesothelioma cell $\bullet$ Apoptosis

\begin{abstract}
Background/Aims: The present study investigated adenosine-induced apoptosis in human malignant pleural mesothelioma cells. Methods: MTT assay, TUNEL staining, flow cytometry using propidium iodide and annexin V-FITC, real-time RT-PCR, Western blotting, and assay of caspase-3, -8 , and -9 activities were carried out using malignant pleural mesothelioma cell lines such as NCI-H28, NCI-H2052, NCI-H2452, and MSTO-211H cells, and p53 or $\mathrm{A}_{3}$ adenosine receptor was knocked-down by transfecting each siRNA into cells. Results: Adenosine induced apoptosis in all the malignant pleural mesothelioma cells used here, independently of caspase activation. The adenosine effect was prevented by the adenosine transporter inhibitor dipyridamole, the adenosine kinase inhibitor $A B T-702$, or the $A_{3}$ adenosine receptor inhibitor MRS1191. Adenosine upregulated expression of the p53 mRNA and protein, that is abolished by ABT-702, but not by knocking-down $\mathrm{A}_{3}$ adenosine receptor. Adenosine-induced apoptosis in NCI-H28 cells was significantly inhibited by knocking-down p53 and in part by knocking-down $\mathrm{A}_{3}$ adenosine receptor. Conclusion: The results of the present study show that AMP converted from intracellularly transported adenosine upregulates p53 expression to induce caspase-independent apoptosis in malignant pleural mesothelioma cells and that $A_{3}$ adenosine receptor also participates partially in the apoptosis by the different mechanism.
\end{abstract}

Copyright $\odot 2012$ S. Karger AG, Basel

\section{Introduction}

Malignant pleural mesothelioma, a highly aggressive neoplasm, has been increasing in incidence and is strongly associated with asbestos exposure [1]. Malignant pleural 


\section{Cellular Physiology Cell Physiol Biochem 2012;30:61-74 \\ \begin{tabular}{ll|l} 
and Biochemistry & $\begin{array}{l}\text { DOI: 10.1159/000339048 } \\
\text { Published online: June 08, } 2012\end{array}$ & $\begin{array}{l}\text { C 2012 S. Karger AG, Bas } \\
\text { www.karger.com/cpb }\end{array}$ \\
\cline { 2 - 3 } Nogi/ Kanno/Nakano et al.: Adenosine-induced Apoptosis in Malignant Pleural
\end{tabular} \\ Nogi/ Kanno/Nakan
Mesothelioma Cells}

mesothelioma is characterized by insidious growth and clinical presentation at an advanced stage of disease. In spite of extensive and intensive challenges, the treatment of malignant pleural mesothelioma has been still limited to marginally effective chemotherapy and morbid surgery.

Higher concentrations of extracellular adenosine are recognized to induce apoptosis in a variety of cancer cells via diverse signaling pathways. The underlying pathways are largely divided into two pathways, i.e., intrinsic and extrinsic pathways. For the intrinsic pathway, the initial step is uptake of extracellular adenosine into cells through adenosine transporters. Intracellularly transported adenosine is converted to AMP by adenosine kinase and activate AMP-activated protein kinase (AMPK), thereby inducing apoptosis in GT3-TKB human lung cancer cells and HuH-7 human hepatoma cells [2, 3]. Intracellularly transported adenosine/ converted AMP downregulates expression of c-Fas-associated death domain protein (FADD)like interleukin-1 $\beta$-converting enzyme inhibitory protein (c-FLIP) to neutralize caspase-8 inhibition due to c-FLIP, resulting in the activation of caspase-8 and the effector caspase-3, to induce $\mathrm{HuH}-7$ cell apoptosis [4]. Intracellularly transported adenosine, alternatively, activates caspase- 3 by neutralizing caspase- 3 inhibition due to inhibitor of apoptosis protein (IAP) as a result of decreased IAP2 expression and reduced IAP activity in response to increased DIABLO expression and DIABLO release from damaged mitochondria in HuH-7 cells, regardless of caspase-9 activation [5]. Moreover, intracellularly transported adenosine induces caspaseindependent apoptosis in MCF-7 human breast cancer cells by accumulating AMID in the nucleus [6] or adenosine induces $\mathrm{HuH}-7$ cell apoptosis in a caspase-independent manner by upregulating expression of AMID [7]. Adenosine also upregulates expression of mRNAs for tumor necrosis factor (TNF), TNF receptor 1-associated death domain protein (TRADD), TNF-related apoptosis inducing ligand receptor 2 (TRAIL-R2), receptor-interacting protein kinase 1 (RIPK1), and FADD in HepG2 human hepatoma cells, which suggests that adenosine induces HepG2 cell apoptosis by activating caspase-8 through a TNFR1/TRADD/RIP1/FADD pathway and the effector caspases-3 [8].

For the extrinsic pathway, adenosine receptors such as $A_{1}, A_{2 a^{\prime}} A_{2 b^{\prime}}$ and $A_{3}$ receptors mediate apoptosis. Adenosine induces apoptosis in CW2 human colonic cancer cells by activating caspase- $3,-8$, and -9 via $A_{1}$ adenosine receptor linked to $G_{i}$ protein [9]. Adenosine induces RCR-1 astrocytoma cell apoptosis by activating caspase-3/-9 in part via $\mathrm{A}_{1}$ adenosine receptor [10]. Adenosine induces apoptosis in Caco-2 human colonic cancer cells by activating caspase-9/-3 via $A_{2 a}$ adenosine receptor linked to $G_{s}$ protein [11] or HepG2 cell apoptosis by downregulating Bcl- $\mathrm{X}_{\mathrm{L}}$ expression and upregulating Bid expression, causing activation of caspase-9/-3, via $A_{2 \mathrm{a}}$ adenosine receptor [12]. $A_{3}$ adenosine receptor, that is linked to $G_{i}$ or $\mathrm{G}_{\mathrm{q}}$ protein, mediates apoptosis in human lung cancer cells, hepatocellular carcinoma cells, thyroid cancer cells, and breast cancer cells [13-16]. A study shows that adenosine prevents malignant pleural mesothelioma cell growth via $\mathrm{A}_{3}$ adenosine receptor [17]. Little, however, is known about adenosine-induced apoptosis in malignant pleural mesothelioma cells.

The present study was designed to explore adenosine-induced apoptosis in human malignant pleural mesothelioma cells and to understand the underlying mechanism. We show here that for a main pathway AMP converted from intracellularly transported adenosine upregulates expression of p53, to induce caspase-independent apoptosis in malignant pleural mesothelioma cells and that for a branch pathway $\mathrm{A}_{3}$ adenosine receptor mediates the apoptosis by the different mechanism.

\section{Materials and Methods}

\section{Cell culture}

Human malignant pleural mesothelioma cell lines such as NCI-H28, NCI-H2052, NCI-H2452, and MSTO-211H cells, originated from the epithelium, were purchased from American Type Culture Collection (Manassas, VA, USA). Cells were grown in RPMI-1640 medium supplemented with 10\% heat-inactivated FBS, $0.003 \%$ L-glutamine, penicillin (final concentration, $100 \mathrm{U} / \mathrm{ml}$ ), and streptomycin (final concentration, $0.1 \mathrm{mg} / \mathrm{ml}$ ), in a humidified atmosphere of $5 \% \mathrm{CO}_{2}$ and $95 \%$ air at $37^{\circ} \mathrm{C}$. 


\section{Cellular Physiology Cell Physiol Biochem 2012;30:61-74 \begin{tabular}{ll|l} 
and BiOChemistry & $\begin{array}{l}\text { DOI: 10.1159/000339048 } \\
\text { Published online: June 08, 2012 }\end{array}$ & $\begin{array}{l}\text { C 2012 S. Karger AG, Basel } \\
\text { www.karger.com/cpb }\end{array}$ \\
\cline { 2 - 3 }
\end{tabular} Nogi/ Kanno/Nakano et al.: Adenosine-induced Apoptosis in Malignant Pleural Mesothelioma Cells}

Table 1. Primers used for real-time RT-PCR

\begin{tabular}{ll}
\hline PCR primers & Oligonucleotide sequence \\
\hline AIF & $\begin{array}{l}\text { Sense: } 5^{\prime} \text {-CACAAAGACACTGCGATTCAAACAGT-3' } \\
\text { Anti-sense: } 5^{\prime} \text {-GTTGCTGAGGTATTCGGGGAGGAT-3' }\end{array}$ \\
AMID & Sense: $5^{\prime}$-GGGTTCGCCAAAAAGACATTCATTT-3' \\
& Anti-sense: $5^{\prime}$-CCTCTGTGCCTTTGTCCGTCTGC-3' \\
p53 & Sense: $5^{\prime}$-GCCATCTACAAGCAGTCACAGCACAT-3' \\
& Anti-sense: $5^{\prime}$-GGCACAAACACGCACCTCAAAGC-3' \\
GAPDH & Sense: $5^{\prime}$-GACTTCAACAGCGACACCCACTCC-3' \\
& Anti-sense: $5^{\prime}$-AGGTCCACCACCCTGTTGCTGTAG-3'
\end{tabular}

Assay of cell viability

Cell viability was evaluated by the method using 3-(4,5-dimethyl-2-thiazolyl)-2,5-diphenyl-2Htetrazolium bromide (MTT) as previously described [2].

Terminal deoxynucleotidyl transferase-mediated dUTP nick end labeling (TUNEL) staining

TUNEL staining was performed to detect in situ DNA fragmentation as a marker of apoptosis using an In Situ Apoptosis Detection Kit (Takara Bio, Otsu, Japan). Briefly, fixed and permeabilized cells were reacted with terminal deoxynucleotidyl transferase and fluorescein isothiocyanate (FITC)-deoxyuridine triphosphate for $90 \mathrm{~min}$ at $37^{\circ} \mathrm{C}$. FITC signals were visualized with a confocal scanning laser microscope (LSM 510, Carl Zeiss Co., Ltd., Oberkochen, Germany).

\section{Apoptosis assay}

Cells were suspended in a binding buffer before and after treatment with adenosine and stained with both propidium iodide (PI) and annexin V-FITC, and loaded on a flow cytometer (FACSCalibur, Becton Dickinson, Franklin Lakes, USA) available for FL1 (annexin V) and FL2 (PI) bivariate analyisis. Data from 10,000 cells/sample were collected, and the quadrants were set according to the population of viable, unstained cells in untreated samples. CellQuest analysis of the data was used to calculate the percentage of the cells in the respective quadrants.

\section{Real-time reverse transcription-polymerase chain reaction (RT-PCR)}

Total RNAs of cells were purified by an acid/guanidine/thiocyanate/chloroform extraction method using the Sepasol-RNA I Super kit (Nacalai, Kyoto, Japan). After purification, total RNAs were treated with RNase-free DNase I ( 2 units) at $37^{\circ} \mathrm{C}$ for 30 min to remove genomic DNAs, and $10 \mu$ g of RNAs was resuspended in water. Then, random primers, $\mathrm{dNTP}, 10 \mathrm{x}$ RT buffer, and Multiscribe Reverse Transcriptase were added to an RNA solution and incubated at $25{ }^{\circ} \mathrm{C}$ for $10 \mathrm{~min}$ followed by $37{ }^{\circ} \mathrm{C}$ for $120 \mathrm{~min}$ to synthesize the first-strand cDNA. Real-time RT-PCR was performed using a SYBR Green Realtime PCR Master Mix (Takara Bio) and the Applied Biosystems 7900 real-time PCR detection system (ABI, Foster City, CA, USA). Thermal cycling conditions were as follows: first step, $94^{\circ} \mathrm{C}$ for $4 \mathrm{~min}$; the ensuing $40 \mathrm{cycles}, 94^{\circ} \mathrm{C}$ for $1 \mathrm{~s}, 65^{\circ} \mathrm{C}$ for 15 $\mathrm{s}$, and $72{ }^{\circ} \mathrm{C}$ for $30 \mathrm{~s}$. The expression level of each mRNA was normalized by that of GAPDH mRNA. Primers used for real-time RT-PCR are shown in Table 1.

\section{Construction and transfection of siRNA}

The siRNA to silence human p53-targeted gene (p53 siRNA) was obtained from Santa Cruz Biotechnology (Santa Cruz, CA, USA), the siRNA to silence GATA-2-targeted gene (GATA-2 siRNA) from Cosmo Bio Co. Ltd. (Tokyo, Japan), and the siRNA to silence the $A_{3}$ adenosine receptor-targeted gene $\left(A_{3} R\right.$ siRNA) and the negative control siRNA (NC siRNA) from Ambion (Austin, TX, USA).

The p53 siRNA, the GATA-2 siRNA, the $A_{3}$ R siRNA, or the NC siRNA was reverse-transfected into cells using a Lipofectamine reagent (Invitrogen, Carlsbad, CA, USA). Cells were used for experiments $48 \mathrm{~h}$ after transfection.

\section{Separation into the nuclear and cytosolic components}

Cells were suspended in buffer A [25 mM MgCl, $0.1 \%$ (v/v) Triton X-100, 1 mM dithiothreitol, and 10 mM HEPES, $\mathrm{pH}$ 7.6] containing $1 \%(\mathrm{v} / \mathrm{v})$ protease inhibitor cocktail, and then centrifuged at 3,500 rpm for $5 \mathrm{~min}$ at $4{ }^{\circ} \mathrm{C}$. The pellet and supernatant were used as nuclei- and cytosol-enriched components. Whether 


\section{Cellular Physiology \\ Cell Physiol Biochem 2012;30:61-74 and Biochemistry

\begin{tabular}{l|l}
\hline DOI: $10.1159 / 000339048$ & C 2012 S. Karger AG, Basel \\
www.karger.com/cpb
\end{tabular} \\ Published online: June 08, 2012 \\ www.karger.com/cpb}

Fig. 1. Cell viability. $\mathrm{NCI}-\mathrm{H} 28$ (A) NCI-H2052 (B), NCI-H2452 (C), and MSTO-211H cells (D) were treated with adenosine at concentrations as indicated for 24-72 h, and cell viability was quantified with an MTT assay. In the graphs, each point represents the mean $( \pm$ SEM) percentage of control (MTT intensities of cells untreated with adenosine $)(n=4$ independent experiments).

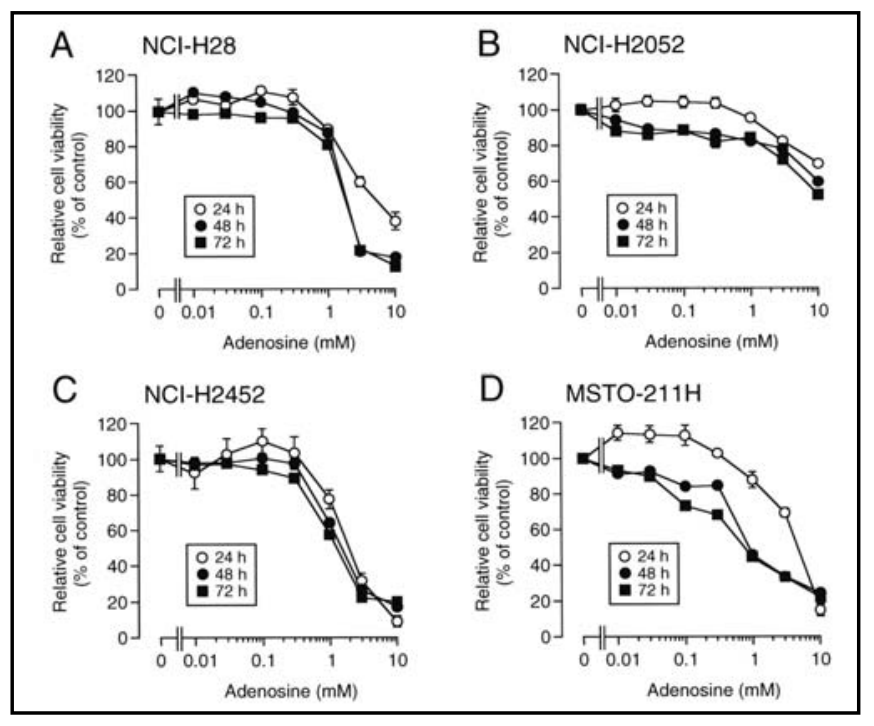

the nuclear and cytosolic components were successfully separated was confirmed by Western blotting using an anti-Lamin A/C antibody, a nuclear marker.

\section{Western blotting}

Cells were lysed with $1 \%(\mathrm{w} / \mathrm{v}$ ) sodium dodecyl sulfate (SDS). Proteins were separated by SDSpolyacrylamide gel electrophoresis (SDS-PAGE) using a TGX gel (BioRad, Hercules, CA, USA) and then transferred to polyvinylidene difluoride membranes. Blotting membranes were blocked with TBS-T [150 $\mathrm{mM} \mathrm{NaCl}, 0.1 \%(\mathrm{v} / \mathrm{v})$ Tween20 and $20 \mathrm{mM}$ Tris, $\mathrm{pH} 7.5$ ] containing 5\% (w/v) bovine serum albumin and subsequently incubated with an anti-AIF antibody (Santa Cruz Biotechnology), an anti-AMID antibody (Santa Cruz Biotechnology), an anti-p53 antibody (Cell Signaling, Beverly, MA, USA), an anti-GATA-2 antibody (Santa Cruz Biotechnology), an anti- $\mathrm{A}_{3}$ receptor antibody (Santa Cruz Biotechnology), or an anti$\beta$-actin antibody (Sigma, St Louis, MO, USA). After washing, membranes were reacted with a horseradish peroxidase-conjugated goat anti-mouse IgG or goat anti-rabbit IgG antibody. Immunoreactivity was detected with an ECL kit (GE Healthcare, Piscataway, NJ, USA) and visualized using a chemiluminescence detection system (GE Healthcare). Protein concentrations for each sample were determined with a BCA protein assay kit (Pierce, Rockford, IL, USA).

\section{Enzymatic assay of caspase-3, -8, and -9 activities}

Caspase activity was measured using a caspase fluorometric assay kit (Ac-Asp-Glu-Val-Asp-MCA for a caspase-3 substrate peptide; Ac-Ile-Glu-Thr-Asp-MCA for a caspase-8 substrate peptide; and Ac-Leu-GluHis-Asp-MCA for a caspase-9 substrate peptide) as previously described [11]. Briefly, NCI-H28 cells were harvested before and after treatment with adenosine, and then centrifuged at 1,200 rpm for 5 min at $4{ }^{\circ} \mathrm{C}$. The pellet was incubated on ice in cell lysis buffer for $10 \mathrm{~min}$, and reacted with the fluorescently labeled tetrapeptide at $37{ }^{\circ} \mathrm{C}$ for $2 \mathrm{~h}$. The fluorescence was measured at an excitation of wavelength of $380 \mathrm{~nm}$ and an emission wavelength of $460 \mathrm{~nm}$ with a fluorometer (Fluorescence Spectrometer, F-4500, HITACHI, Japan).

\section{Statistical analysis}

Statistical analysis was carried out using unpaired $t$-test and Dunnett's test.

\section{Results}

Extracellular adenosine induces apoptosis in malignant pleural mesothelioma cells via both the extrinsic and intrinsic pathways

In the MTT assay, extracellular adenosine reduced cell viability for all the malignant pleural mesothelioma cells used here such as NCI-H28, NCI-H2052, NCI-H2452, and MSTO$211 \mathrm{H}$ cells in a concentration (0.01-10 mM)- and treatment time (24-72h)-dependent 


\section{Cellular Physiology Cell Physiol Biochem 2012;30:61-74

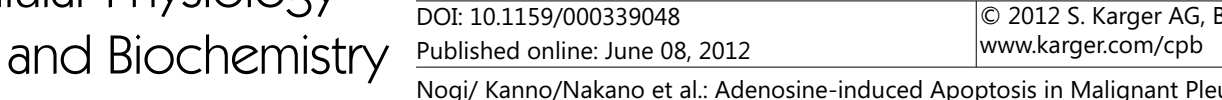 Nogi/ Kanno/Nakano et al.: Adenosine-induced Apoptosis in Malignant Pleural Mesothelioma Cells}

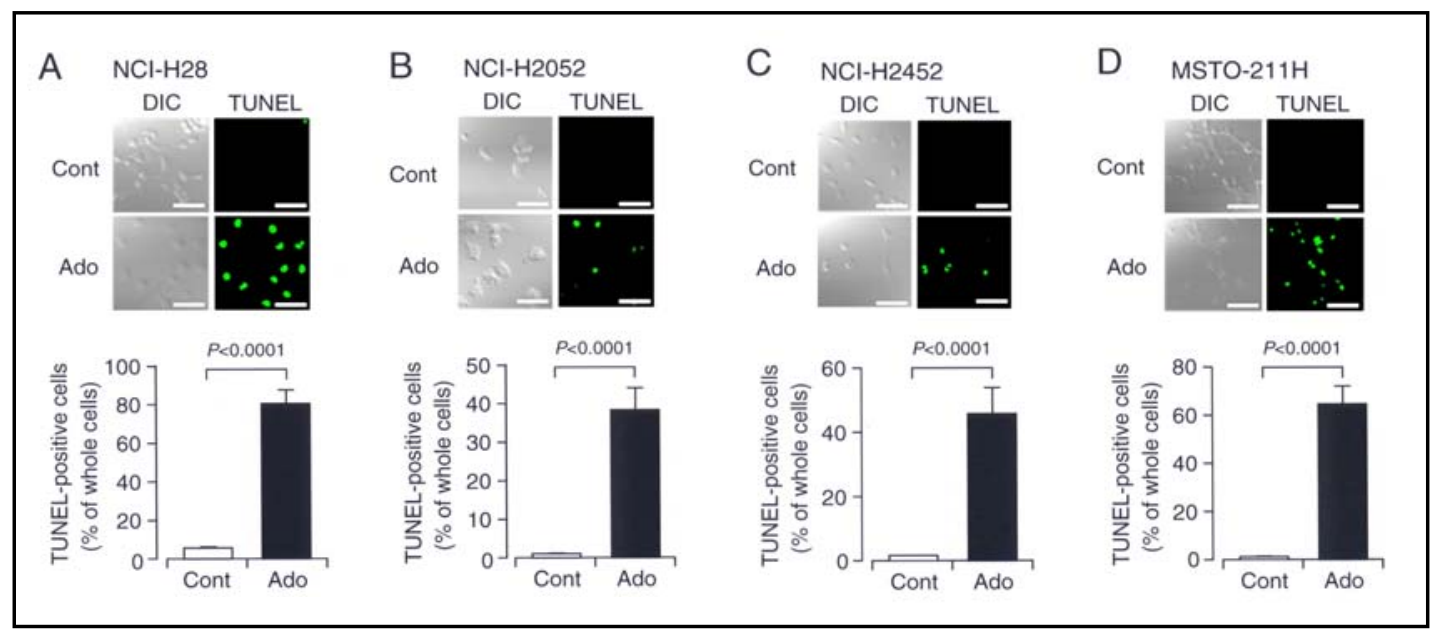

Fig. 2. TUNEL staining. TUNEL staining was carried out in NCI-H28 (A), NCI-H2052 (B), NCI-H2452 (C), and MSTO-211H cells (D) untreated (Cont) and treated with adenosine (Ado)(3 mM) for $24 \mathrm{~h}$. DIC, differential interference contrast. Bars, $100 \mu \mathrm{m}$. TUNEL-positive cells were counted in the area $(0.4 \mathrm{~mm} \times 0.4 \mathrm{~mm})$ selected at random. In the graphs, each column represents the mean ( \pm SEM) TUNEL-positive cell percentage of whole cells ( $\mathrm{n}=4$ independent experiments). $P$ values, unpaired $t$-test.

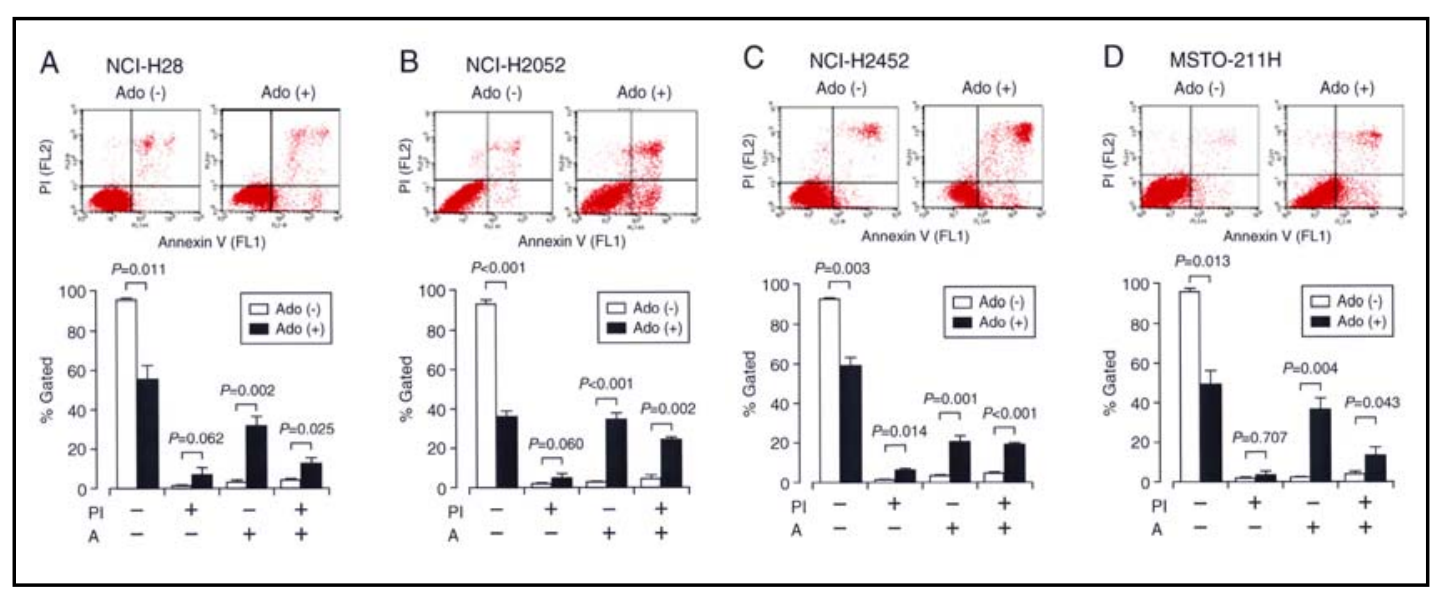

Fig. 3. Flow cytometry. NCI-H28 (A), NCI-H2052 (B), NCI-H2452 (C), and MSTO-211H cells (D) were untreated [Ado $(-)]$ and treated with adenosine $(3 \mathrm{mM})$ for $24 \mathrm{~h}[$ Ado $(+)]$, and then flow cytometry using PI and annexin V-FITC was carried out. Typical profiles are shown in the upper panels. In the graphs, each column represents the mean $( \pm$ SEM) percentage of cells in 4 fractions against total cells $(n=4$ independent experiments). $P$ values, Dunnett's test.

manner, with the order of the potential for: NCI-H2452 cells $>\mathrm{NCI}-\mathrm{H} 28$ cells $>\mathrm{MSTO}-211 \mathrm{H}$ cells $>$ NCI-H2052 cells (Fig. 1A,B,C,D). This indicates that adenosine induces cell death in malignant pleural mesothelioma cells, although the potential varies depending upon the cell types.

To see whether the adenosine-induced cell death is due to necrosis or apoptosis, we carried out TUNEL staining. Treatment with adenosine $(3 \mathrm{mM})$ for $24 \mathrm{~h}$ significantly increased the number of TUNEL-positive cells as compared with that before adenosine treatment commonly for all the malignant pleural mesothelioma cells examined here with the degree varying among cell types (Fig. $2 \mathrm{~A}, \mathrm{~B}, \mathrm{C}, \mathrm{D}$ ). This indicates that adenosine induces apoptosis in malignant pleural mesothelioma cells.

To obtain further evidence for adenosine-induced apoptosis, we carried out flow cytometry using PI and annexin V-FITC. PI is a marker of dead cells and annexin V, detecting 


\section{Cellular Physiology \\ Cell Physiol Biochem 2012;30:61-74 and Biochemistry

\begin{tabular}{l|l} 
DOI: $10.1159 / 000339048$ & $\begin{array}{l}\text { C } 2012 \text { S. Karger AG, Basel } \\
\text { www.karger.com/cpb }\end{array}$ \\
Published online: June 08, 2012 & \multicolumn{1}{|l}{ Nogi/ Kanno/Nakano et al.: Adenosine-induced Apoptosis in Malignant Pleural }
\end{tabular}

Fig. 4. Pharmacological analysis using inhibitors. NCI-H28 (A), NCI-H2052 (B), NCI-H2452 (C), and MSTO-211H cells (D) were treated with adenosine $(3 \mathrm{mM})$ in the absence and presence of 8-CPT $(10 \mu \mathrm{M})$, DMPX $(10 \mu \mathrm{M})$, MRS1706 (50 nM), MRS1191 (10 $\mu \mathrm{M})$, dipyridamole $(10 \mu \mathrm{M})$, ABT-702 (1 $\mu \mathrm{M})$, Compound C $(10 \mu \mathrm{M})$, or EHNA $(10 \mu \mathrm{M})$ for $24 \mathrm{~h}$, and then, MTT assay was carried out. In the graphs, each column represents the mean $( \pm$ SEM) percentage of basal levels (MTT intensities of cells untreated with adenosine in the absence of inhibitors)( $n=4$ independent experiments). $P$ values, Dunnett's test.

Fig. 5. Caspase activity. (A) NCI-H28 cells were treated with adenosine $(3$ $\mathrm{mM}$ ) in the presence and absence of Z-VAD-fmk $(100 \mu \mathrm{M})$ for 24 $h$, followed by MTT assay. In the graph, each column represents the mean $( \pm$ SEM) percentage of control (MTT intensities of cells untreated with adenosine in the absence of the Z-VAD-fmk)(n=4 independent experiments).

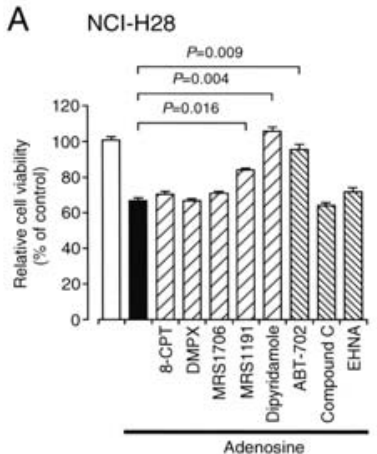

B $\quad \mathrm{NCl}-\mathrm{H} 2052$

C NCl-H2452
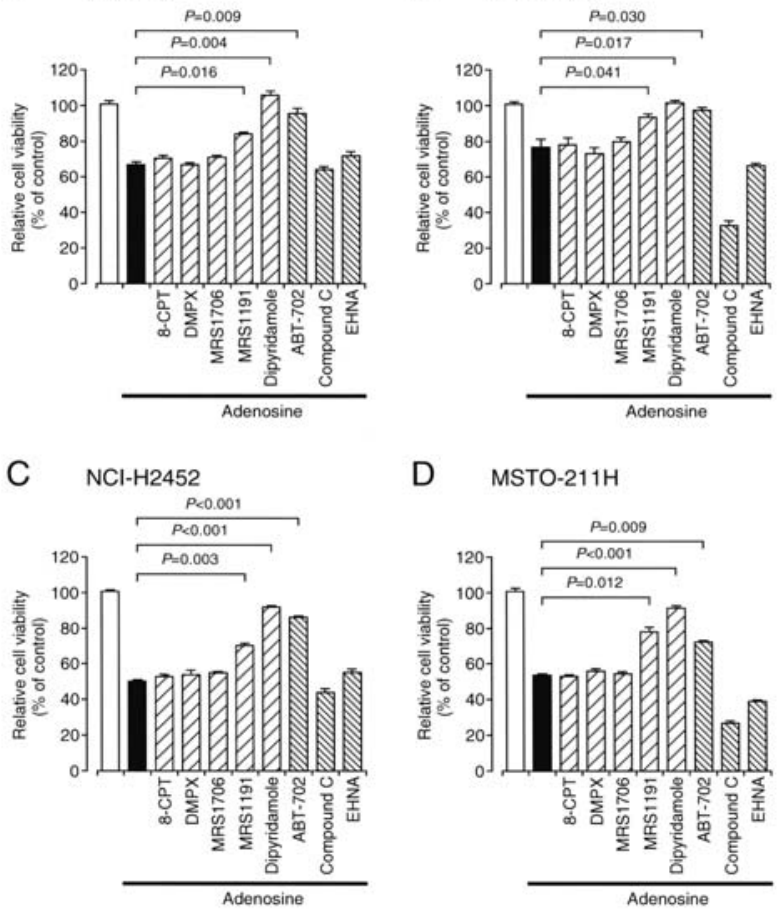

D MSTO-211H

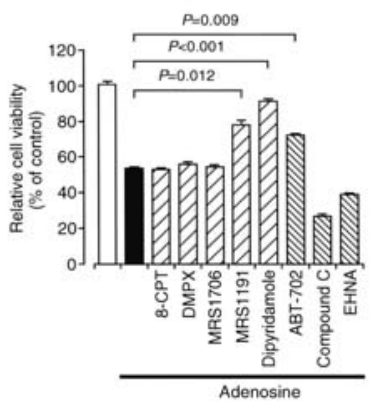

B
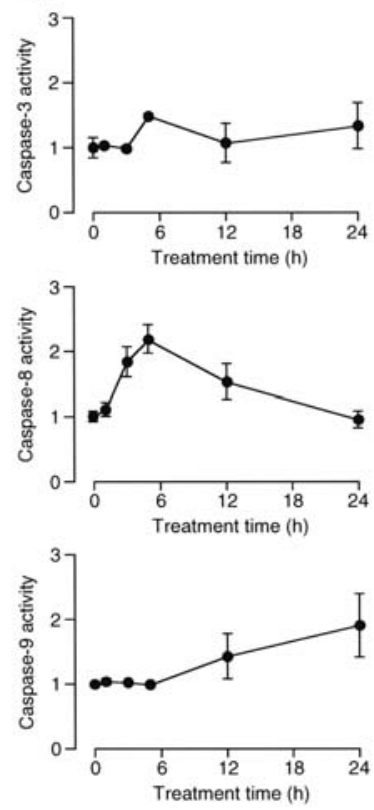

externalized phosphatidylserine residues, is a marker of apoptotic cells [18]. For all the cell types, 24-h treatment with adenosine $(3 \mathrm{mM})$ markedly decreased the population of PInegative and annexin V-negative cells, but otherwise it significantly increased the population of PI-negative and annexin V-positive cells and the population of PI-positive and annexin Vpositive cells, each corresponding to early apoptosis and late apoptosis/secondary necrosis [19](Fig. 3A,B,C,D). Collectively, these results provide evidence for adenosine-induced apoptosis in malignant pleural mesothelioma cells.

For all the malignant pleural mesothelioma cells used here, adenosine-induced cell death was significantly inhibited by 3-ethyl 5-benzyl-2- methyl-6-phenyl-4-phenylethynyl- 


\section{Cellular Physiology Cell Physiol Biochem 2012;30:61-74

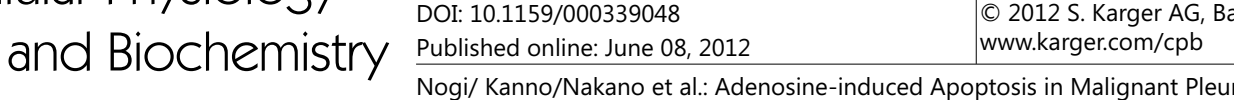 \\ Nogi/ Kanno/Nakano
Mesothelioma Cells}

Fig. 6. Expression and intracellular distribution of AIF and AMID. (A) NCI-H28 cells were treated with adenosine $(3 \mathrm{mM})$ for periods of time as indicated, and then real-time RT-PCR was carried out. Signal intensities for the AIF and AMID mRNAs were normalized by the intensity for the GAPDH mRNA. In the graphs, each point represents the mean ( \pm SEM) normalized AIF or AMID mRNA intensity $(\mathrm{n}=4$ independent experiments). (B) NCI-H28 cells were treated with adenosine $(3 \mathrm{mM})$ for periods of time as indicated, and then Western blotting was carried out. Signal intensities for AIF or AMID protein were normalized by the intensity for $\beta$-actin. In the graphs, each point represents the mean $( \pm$ SEM) ratio against signal intensities for AIF or AMID protein at $0 \mathrm{~h}(\mathrm{n}=4$ independent experiments). (C) NCI-H28 cells treated with adenosine (3 $\mathrm{mM}$ ) for periods of time as indicated were lysed and separated into the nuclear $(N)$ and cytosolic components $(C)$, followed by Western blotting. In the graphs, each point represents the mean $( \pm$ SEM) ratio: nuclear AIF or AMID/whole cell AIF or AMID ( $n=4$ independent experiments).

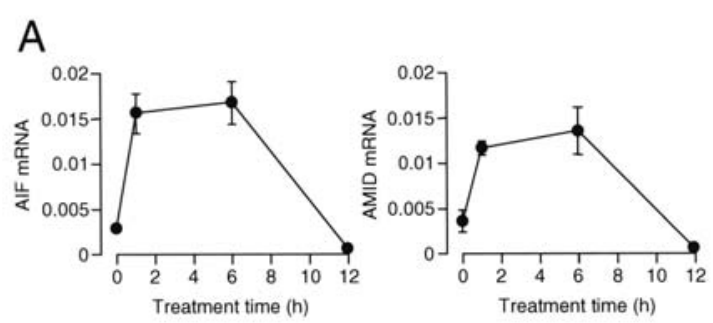

B
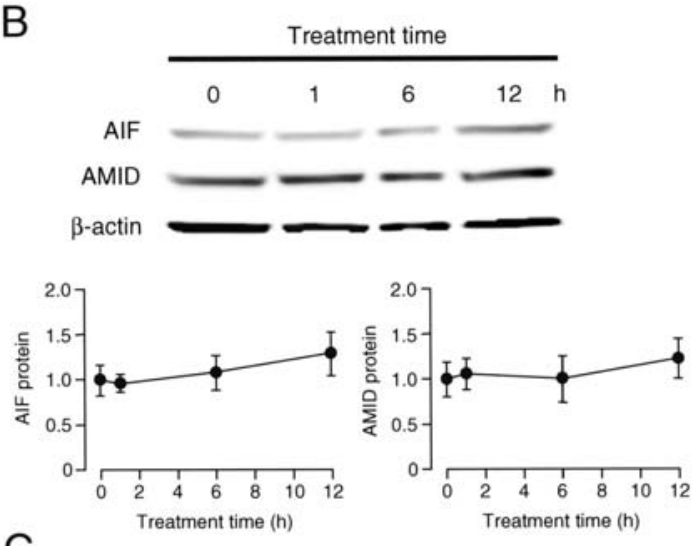

C

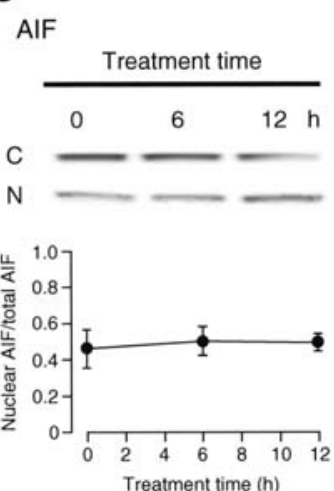

AMID
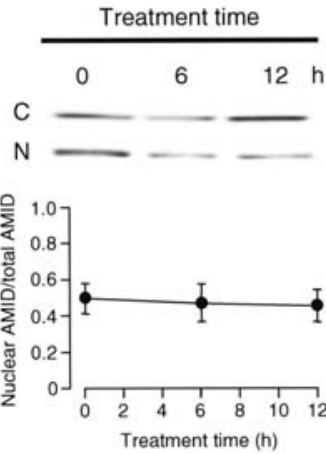

1,4-( \pm )-dihydropyridine-3,5-dicarboxylate (MRS1191), an inhibitor of $A_{3}$ adenosine receptors, while it was not affected by 8-cyclopentyltheophylline (8-CPT), an inhibitor of $A_{1}$ adenosine receptors, 3,7-dimethyl-1 propargylxanthine (DMPX), an inhibitor of $\mathrm{A}_{2 \mathrm{a}}$ adenosine receptors, or $N$-(4-acetylphenyl)-2-[4-(2,3,6,7-tetrahydro-2,6-dioxo-1,3-dipropyl-1H-purin8-yl)phenoxy] acetamide (MRS1706), an inhibitor of $\mathrm{A}_{2 \mathrm{~b}}$ adenosine receptors (Fig. 4A,B,C,D). This indicates that $A_{3}$ adenosine receptor participates in malignant pleural mesothelioma cell death, i.e., adenosine induces apoptosis in malignant pleural mesothelioma cells through an extrinsic pathway.

Adenosine-induced cell death for malignant pleural mesothelioma cells, alternatively, was neutralized by dipyridamole, an adenosine transporter inhibitor (Fig. 4A,B,C,D), indicating the participation of intrinsic pathway too in adenosine-induced malignant pleural mesothelioma cell death. The adenosine-induced cell death was also significantly suppressed by 4-amino-5-(3-bromophenyl)-7-(6-morpholino-pyridin-3-yl)pyrido[2,3-d] pyrimidine (ABT-702), an inhibitor of adenosine kinase to phosphorylate adenosine and convert to AMP, but it was not affected by Compound C, an inhibitor of AMPK (Fig. 4A,B,C,D). This interprets that AMP converted from intracellularly transported adenosine mediates adenosine-induced apoptosis in malignant pleural mesothelioma cells, without AMPK activation. Moreover, the adenosine-induced cell death was not inhibited by erythro-9-(2-hydroxy-3-nonyl) adenine 


\section{Cellular Physiology $\quad$ Cell Physiol Biochem 2012;30:61-74 \\ \begin{tabular}{ll|l} 
and BiOChemistry & $\begin{array}{l}\text { DOI: 10.1159/000339048 } \\
\text { Published online: June 08, 2012 }\end{array}$ & $\begin{array}{l}\text { C 2012 S. Karger AG, Base } \\
\text { www.karger.com/cpb }\end{array}$ \\
\cline { 2 - 3 } Nogi/ Kanno/Nakano et al.: Adenosine-induced Apoptosis in Malignant Pleural
\end{tabular} Nogi/ Kanno/Nakano
Mesothelioma Cells}

Fig. 7. p53 expression. NCIH28 cells were treated with adenosine ( $3 \mathrm{mM}$ ) for periods of time as indicated, followed by real-time RT-PCR (A) and Western blotting (B). (A) Signal intensities for the p53 mRNA was normalized by the intensity for the GAPDH mRNA. In the graph, each point represents the mean ( \pm SEM) normalized p53 mRNA intensity $(\mathrm{n}=4$ independent experiments). ${ }^{*} P<0.01$ as compared with

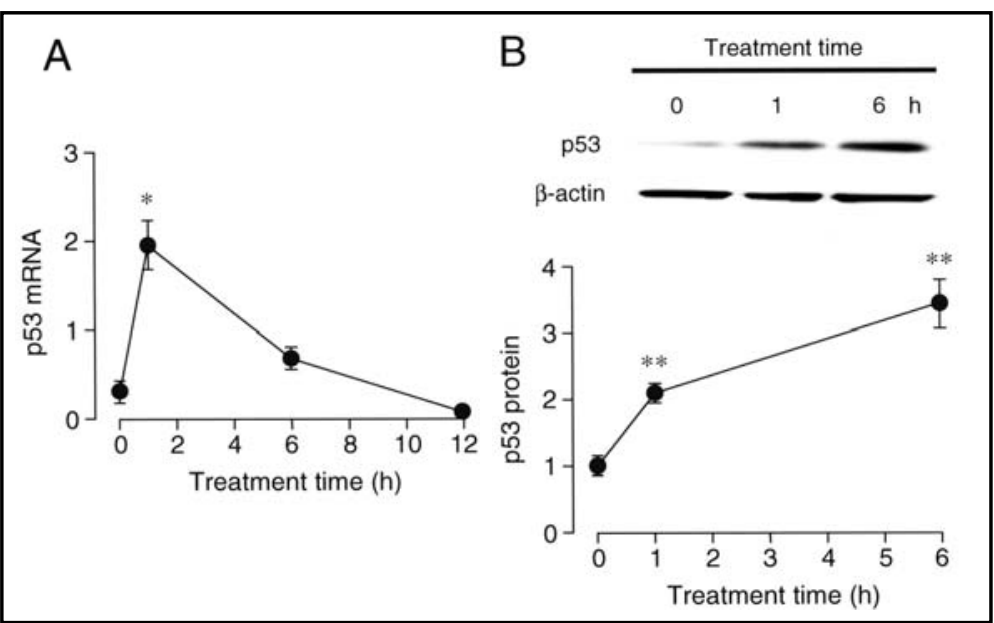
basal levels $(0 \mathrm{~h})$, Dunnett's test. (B) Signal intensities for p53 protein were normalized by the intensity for $\beta$-actin. In the graph, each point represents the mean $( \pm$ SEM) ratio against $p 53$ signal intensities at $0 \mathrm{~h}(\mathrm{n}=4$ independent experiments). ${ }^{* *} P<0.001$ as compared with basal levels $(0 \mathrm{~h})$, Dunnett's test.

(EHNA), an inhibitor of adenosine deaminase (Fig. 4A,B,C,D), indicating that the adenosine effect is not caused by adenosine metabolites such as hypoxanthine and inosine.

Adenosine-induced apoptosis in NCI-H28 cells is largely independent of caspase activation

We next attempted to understand the intracellular signaling underlying adenosineinduced apoptosis in malignant pleural mesothelioma cells. To address this question, we picked up NCI-H28 cells with a moderate adenosine effect among 4 cell lines and used them for the following experiments.

Adenosine-induced NCI-H28 cell death was little inhibited by the pan-caspase inhibitor Z-VAD-fmk (Fig. 5A), suggesting caspase-independent apoptosis.

To further clarify this, we enzymatically assayed activities of caspase- $3,-8$, and -9 . No apparent activation of caspase-3, -8, or -9 in NCI-H28 cells was obtained with adenosine (Fig. 5B), supporting the note that adenosine induces apoptosis in NCI-H28 cells largely in a caspase-independent manner.

In our earlier study, adenosine induces caspase-independent apoptosis in HuH-7 human hepatoma cells by upregulating AMID [7]. For a caspase-independent apoptotic pathway, AMID as well as AIF are the major executioners. AIF, that is localized within the mitochondrial membrane under the normal conditions, is released from the mitochondria in response to lethal signals, translocated into the nucleus, and binds to the nuclear DNA, thereby causing chromosomal condensation, margination, and large-scale DNA fragmentation [20-22]. Likewise, AMID induces apoptosis by accumulating in the nucleus [23-28]. In the present study, adenosine increased expression of mRNAs for AIF and AMID in a bell-shaped treatment time (1-12 h)-dependent manner in NCI-H28 cells (Fig. 6A). Strangely, adenosine did not alter expression of proteins for AIF and AMID in NCI-H28 cells (Fig. 6B). Additionally, no translocation of AIF or AMID from the cytosol into the nucleus was found with adenosine (Fig. 6C). Overall, these results indicate that adenosine induces caspase-independent apoptosis in NCI-H28 cells, regardless of AIF or AMID.

\section{Adenosine induces NCI-H28 cell apoptosis in a p53-dependent manner}

The tumor suppressor protein p53 is well-recognized to induce cancer cell apoptosis via transcription-dependent and -independent pathways. Then, our final attempt was to see whether $\mathrm{p} 53$ is implicated in adenosine-induced apoptosis here. For NCI-H28 cells, adenosine increased expression of the p53 mRNA in a bell-shaped treatment time (1-12 h)-dependent manner (Fig. 7A) and p53 protein in a treatment time (1-6 h)-dependent manner (Fig. 7B). This accounts for adenosine-induced upregulation of p53 expression in NCI-H28 cells. 


\section{Cellular Physiology and Biochemistry \\ Cell Physiol Biochem 2012;30:61-74 \\ \begin{tabular}{l|l}
\hline DOI: 10.1159/000339048 & C 2012 S. Karger AG, Basel
\end{tabular} \\ Published online: June 08, 2012 \\ www.karger.com/cpb}

Fig. 8. p53-dependent apoptosis. (A) NCI-H28 cells were transfected with the NC siRNA or the p53 siRNA, and Western blotting was carried out $48 \mathrm{~h}$ after transfection. The signal intensity for $\mathrm{p} 53$ protein was normalized by the intensity for $\beta$-actin. In the graph, each column represents the mean ( \pm SEM) ratio against $\mathrm{p} 53$ protein signal intensities for cells transfected with the NC siRNA ( $n=4$ independent experiments). $P$ value, unpaired $t$ test. (B) NCI-H28 cell viability was assayed in cells transfected with the NC siRNA or the p53 siRNA before and after 24-h treatment with adenosine (Ado)(3 mM). In the graph, each column represents the mean $( \pm$ SEM) percentage of basal levels (MTT intensities of cells untreated with adenosine)(n=4 independent experiments). $P$ value, Dunnett's test. (C) TUNEL staining was carried out in NCI-H28 cells transfected with the NC siRNA or the p53 siRNA before (Cont) and after 24-h treatment with adenosine

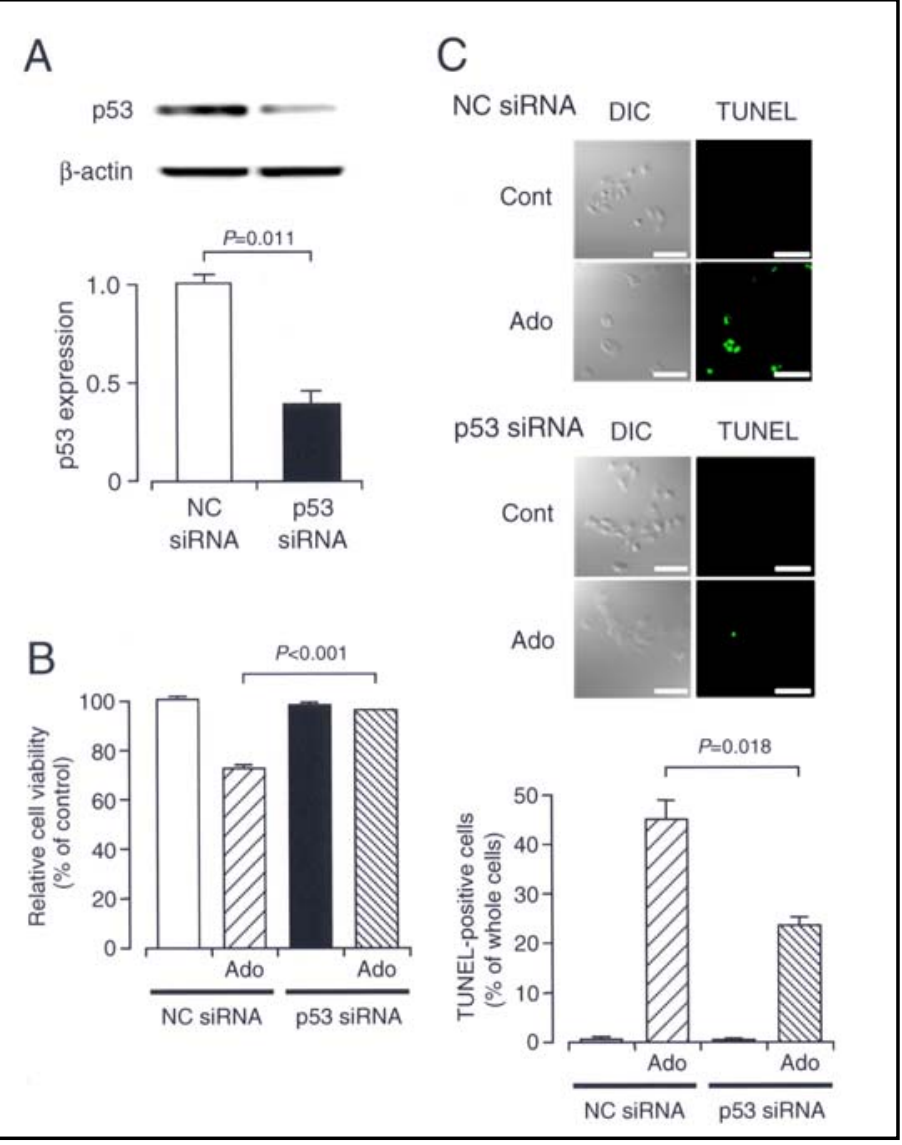
(Ado)(3 mM). DIC, differential interference contrast. Bars, $100 \mu \mathrm{m}$. TUNEL-positive cells were counted in the area $(0.4 \mathrm{~mm} \times 0.4 \mathrm{~mm})$ selected at random. In the graph, each column represents the mean $( \pm$ SEM) TUNEL-positive cell percentage of whole cells $(n=4$ independent experiments). $P$ value, Dunnett's test.

Expression of p53 protein for NCI-H28 cells transfected with the p53 siRNA was significantly attenuated as compared with the expression for cells transfected with the NC siRNA (Fig. $8 \mathrm{~A})$, confirming p53 knock-down. Adenosine-induced NCI-H28 cell death was significantly prevented by knocking-down p53 (Fig. 8B). In addition, adenosine-induced increase in TUNEL-positive cells was also significantly suppressed by knocking-down p53 (Fig. 8C). Taken together, these results indicate that adenosine induces NCI-H28 cell apoptosis by upregulating p53 expression.

We have earlier found that adenosine upregulates p53 expression by targeting GATA-2, thereby activating caspase- $3,-8$, and -9 to induce HepG2 cell apoptosis [29]. To see whether adenosine-induced upregulation of p53 expression in NCI-H28 cells is regulated by GATA2 , the GATA-2 siRNA was transfected into cells. Expression of GATA-2 protein for NCI-H28 cells transfected with the GATA-2 siRNA was significantly reduced as compared with the expression for cells transfected with the NC siRNA (Fig. 9A), confirming GATA-2 knockdown. Adenosine-induced upregulation of p53 mRNA expression in NCI-H28 cells was not affected by knocking-down GATA-2 (Fig. 9B). This indicates that adenosine promotes the p53 transcription in NCI-H28 cells in a GATA-2-independent manner.

For NCI-H28 cells transfected with the $\mathrm{A}_{3} \mathrm{R}$ siRNA, expression of $\mathrm{A}_{3}$ adenosine receptor protein was significantly suppressed as compared with the expression for cells transfected with the NC siRNA (Fig. 9C), confirming $\mathrm{A}_{3}$ adenosine receptor knock-down. Adenosineinduced upregulation of p53 mRNA expression in NCI-H28 cells was not influenced by knocking-down $A_{3}$ adenosine receptor (Fig. 9D). This indicates that $A_{3}$ adenosine receptor is not implicated in the upregulation of p53 expression for NCI-H28 cells. 


\section{Cellular Physiology $\quad$ Cell Physiol Biochem 2012;30:61-74

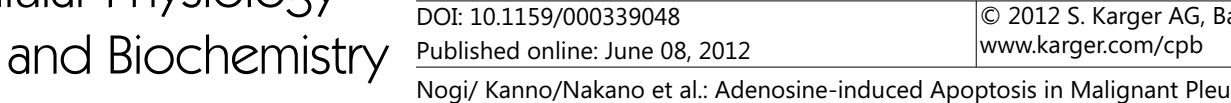 \\ Nogi/ Kanno/Nakano
Mesothelioma Cells}

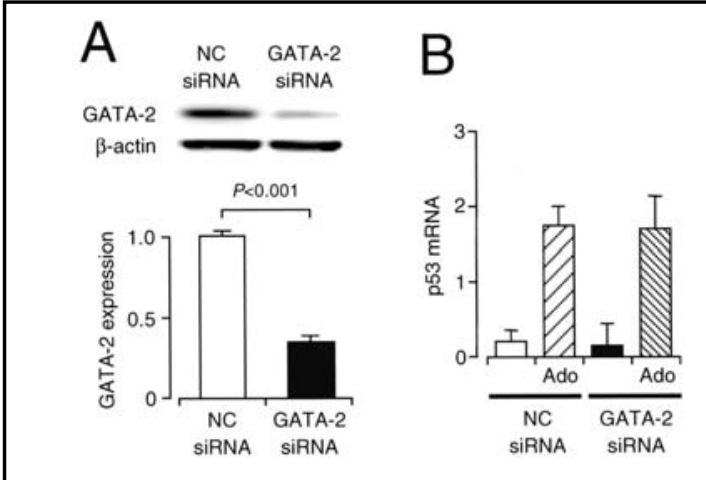

Fig. 9. Regulation of p53 expression. (A) NCI-H28 cells were transfected with the NC siRNA or the GATA-2 siRNA, and Western blotting was carried out $48 \mathrm{~h}$ after transfection. The signal intensity for GATA-2 protein was normalized by the intensity for $\beta$-actin. In the graph, each column represents the mean $( \pm$ SEM) ratio against GATA-2 protein signal intensities for cells transfected with the NC siRNA ( $\mathrm{n}=4$ independent experiments). $P$ value, unpaired $t$-test. (B) Real-time RT-PCR was carried out in cells transfected with the NC siRNA or the GATA-2 siRNA before and after 1-h treatment with adenosine (Ado)(3 $\mathrm{mM}$ ). Signal intensities for the p53 mRNA was normalized by the intensity for the GAPDH mRNA. In the graph, each column represents the mean $( \pm$ SEM) normalized p53 mRNA intensity ( $n=4$ independent experiments). (C) NCI-H28 cells were transfected with the NC siRNA or the $\mathrm{A}_{3} \mathrm{R}$ siRNA, and Western blotting was carried out $48 \mathrm{~h}$ after transfection. The signal intensity for $\mathrm{A}_{3}$ adenosine receptor protein was normalized by the intensity for $\beta$-actin. In the graph, each column represents the mean $\left( \pm\right.$ SEM) ratio against $A_{3}$ adenosine receptor protein signal intensities for cells transfected with the NC siRNA ( $\mathrm{n}=4$ independent experiments). $P$ value, unpaired $t$-test. (D) Real-time RT-PCR was carried out in cells transfected with the NC siRNA or the $A_{3} R$ siRNA before and after 1-h treatment with adenosine (Ado)(3 mM). Signal intensities for the p53 mRNA was normalized by the intensity for the GAPDH mRNA. In the graph, each column represents the mean $( \pm$ SEM) normalized p53 mRNA intensity ( $n=4$ independent experiments). (E) Real-time RT-PCR was carried out in NCI-H28 cells before and after 1-h treatment with adenosine (Ado)(3 mM) in the presence and absence of ABT-702 $(1 \mu \mathrm{M})$. Signal intensities for the p53 mRNA was normalized by the intensity for the GAPDH mRNA. In the graph, each column represents the mean ( \pm SEM) normalized p53 mRNA intensity (n=4 independent experiments). $P$ value, Dunnett's test.

Amazingly, adenosine-induced upregulation of p53 mRNA expression in NCI-H28 cells was drastically inhibited by the adenosine kinase inhibitor ABT-702 (Fig. 9E). This implies that AMP serves as a critical regulator for the p53 transcription.

Adenosine-induced reduction in NCI-H28 cell viability and adenosine-induced increase in TUNEL-positive cells was also inhibited by knocking-down $\mathrm{A}_{3}$ adenosine receptor, but with a lesser degree as compared with that for knocking-down p53 (Fig. 10A,B). This suggests that $\mathrm{A}_{3}$ adenosine receptor in part mediates NCI-H28 cell apoptosis by the mechanism distinct from AMP-mediated p53 upregulation.

\section{Discussion}

The results of the present study clearly demonstrate that extracellular adenosine induces apoptosis in malignant pleural mesothelioma cells such as NCI-H28, NCI-H2052, NCI-H2452, and MSTO-211H cells in a concentration (0.01-10 mM)- and treatment time (24$72 \mathrm{~h}$ )-dependent manner, although the potential varies depending upon the cell types.

Accumulating evidence has shown that adenosine induces apoptosis in variety of cancer cells mainly through two pathways, i.e., an intrinsic pathway relevant to adenosine uptake 


\section{Cellular Physiology Cell Physiol Biochem 2012;30:61-74

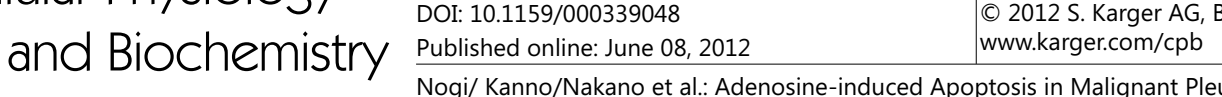 Nogi/ Kanno/Nakano et al.: Adenosine-induced Apoptosis in Malignant Pleural Mesothelioma Cells}

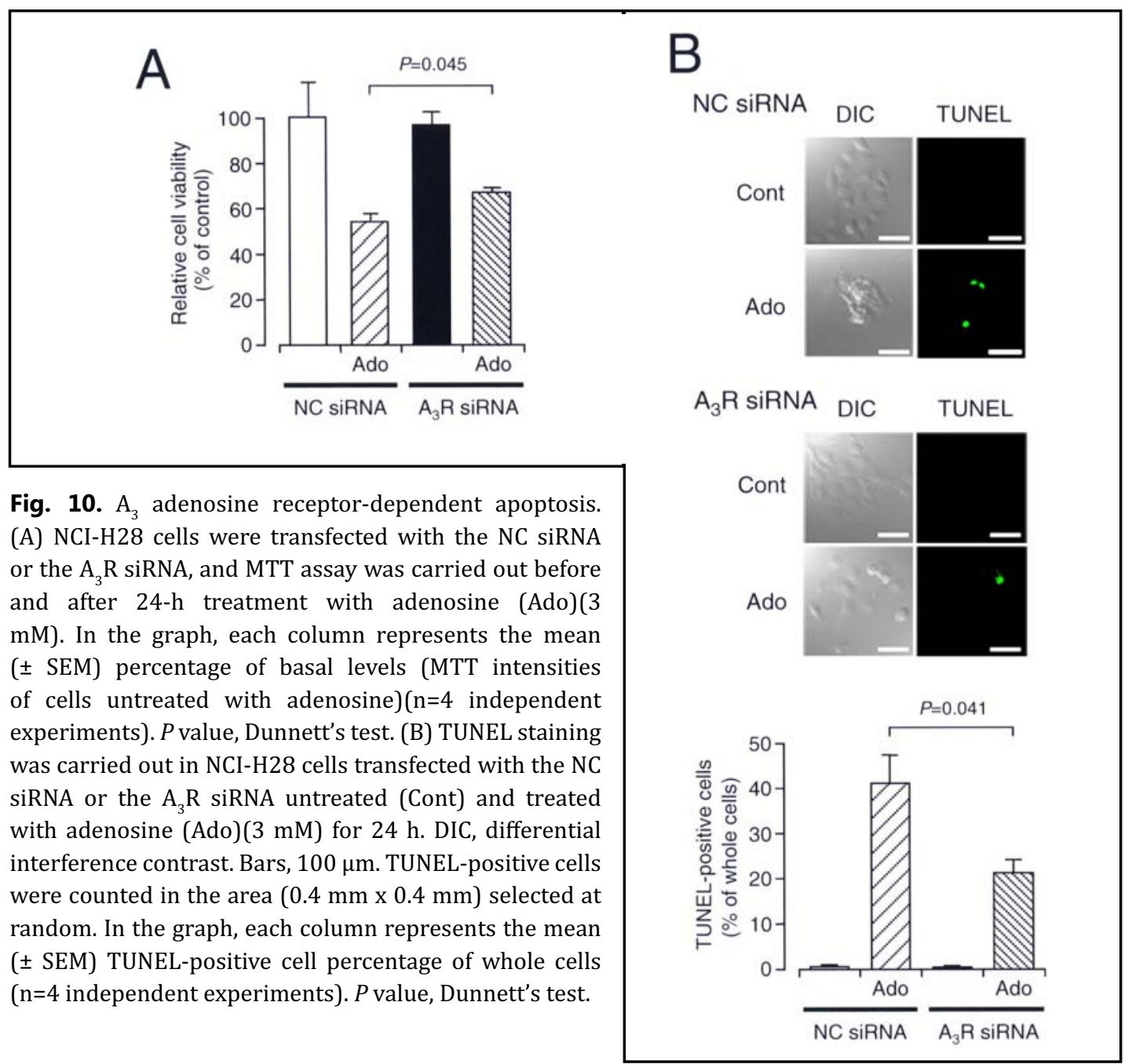

into cells and the ensuing signaling and an extrinsic pathway relevant to adenosine receptors that include $A_{1}, A_{2 a}, A_{2 b}$, and $A_{3}$ receptor. Adenosine-induced apoptosis in malignant pleural mesothelioma cells used here was almost reversed by the adenosine transporter inhibitor dipyridamole or the adenosine kinase inhibitor ABT-702. This interprets that extracellular adenosine induces apoptosis in malignant pleural mesothelioma cells via an intrinsic pathway, i.e., adenosine uptake into cells through adenosine transporters and ensuing conversion to AMP catalyzed by adenosine kinase. AMPK is shown to function downstream AMP, to induce apoptosis in GT3-TKB human lung cancer cells and HuH-7 human hepatoma cells [2, 3]. The adenosine effect here was not affected by the AMPK inhibitor Compound C. This suggests that AMPK is not a downstream target of AMP converted from intracellularly transported adenosine, responsible for adenosine-induced apoptosis in malignant pleural mesothelioma cells. Moreover, the adenosine effect was not inhibited by the adenosine deaminase inhibitor EHNA, indicating no participation of adenosine metabolites such as hypoxanthine and inosine in adenosine-induced malignant pleural mesothelioma cell apoptosis.

Adenosine-induced apoptosis in malignant pleural mesothelioma cells, alternatively, was significantly inhibited by the $A_{3}$ adenosine receptor inhibitor MRS1191, while the $A_{1}$ adenosine receptor inhibitor 8-CPT, the $\mathrm{A}_{2 \mathrm{a}}$ adenosine receptor inhibitor DMPX, or the $\mathrm{A}_{2 \mathrm{~b}}$ adenosine receptor inhibitor MRS1706 had no effect. This indicates that extracellular adenosine also induces apoptosis in malignant pleural mesothelioma cells via an extrinsic pathway, i.e., via an $\mathrm{A}_{3}$ adenosine receptor.

Two major pathways for apoptosis include caspase-dependent and -independent pathways. In the present study, adenosine-induced NCI-H28 cell death was not significantly 


\section{Cellular Physiology Cell Physiol Biochem 2012;30:61-74 \\ \begin{tabular}{ll|l} 
and Biochemistry & $\begin{array}{l}\text { DOI: 10.1159/000339048 } \\
\text { Published online: June 08, } 2012\end{array}$ & $\begin{array}{l}\text { C 2012 S. Karger AG, Bas } \\
\text { www.karger.com/cpb }\end{array}$ \\
\cline { 2 - 3 } Nogi/ Kanno/Nakano et al.: Adenosine-induced Apoptosis in Malignant Pleural
\end{tabular} \\ Nogi/ Kanno/Nakan
Mesothelioma Cells}

inhibited by the pan-caspase inhibitor Z-VAD-fmk. In addition, no remarkable activation of caspase-3, -8, and -9 was found with adenosine for NCI-H28 cells. Likewise, adenosineinduced cell death for the other cell lines NCI-H2052, NCI-H2452, and MSTO-211H cells was not significantly prevented by Z-VAD-fmk, and adenosine did not activate caspase- $3,-8$, and -9 in those cells (data not shown). Collectively, extracellular adenosine is likely to induce malignant pleural mesothelioma cell apoptosis mainly in a caspase-independent manner.

Then, one would ask the question how extracellular adenosine induces malignant pleural mesothelioma cell apoptosis. For a caspase-independent apoptotic pathway, AIF and AMID are recognized to serve as the major executioner. AIF and AMID induce apoptosis by accumulating in the nucleus [20-28]. We have earlier found that extracellular adenosine induces caspase-independent apoptosis in MCF-7 human breast cancer cells by accumulating AMID in the nucleus [6] or in HuH-7 cell apoptosis by upregulating expression of AMID [7]. In the present study, adenosine did not affect expression of proteins for AIF and AMID or intracellular distribution of AIF and AMID in NCI-H28 cells. This suggests no implication of AIF or AMID in adenosine-induced apoptosis in malignant pleural mesothelioma cells.

To explore the mechanism underlying adenosine-induced malignant pleural mesothelioma cell apoptosis, we highlighted p53, a tumor suppressor protein, bearing apoptosis in a wide variety of cancers. Amazingly, adenosine increased expression of the p53 mRNA and protein in NCI-H28 cells, and adenosine-induced NCI-H28 cell apoptosis was significantly prevented by knocking-down p53. Adenosine-induced upregulation of p53 expression and p53-dependent apoptosis were still obtained with the other cell lines NCI-H2052, NCI-H2452, and MSTO-211H cells (data not shown). These results raise the possibility that adenosine induces apoptosis in malignant pleural mesothelioma cells by upregulating p53 expression. In our earlier study, adenosine upregulated p53 expression under the control of GATA-2, responsible for adenosine-induced HepG2 cell apoptosis [29]. Adenosine-induced upregulation of p53 expression in NCI-H28 cells, however, was not affected by knocking-down GATA-2, indicating that adenosine here upregulates p53 expression, independently of GATA-2. Furthermore, the adenosine effect was not also inhibited by knocking-down $\mathrm{A}_{3}$ adenosine receptor, indicating no mediation of the receptor in the p53 transcription for malignant pleural mesothelioma cells. The most striking finding in the present study is that adenosine-induced upregulation of p53 expression in NCI-H28 cells was completely inhibited by the adenosine kinase inhibitor ABT-702. This strongly suggests that AMP converted from intracellularly transported adenosine is engaged in the promotion of the p53 gene transcription. To our knowledge, this is the first suggesting AMP as a critical regulator for the p53 gene transcription.

Adenosine-induced apoptosis in NCI-H28 cells were still suppressed by knocking-down $\mathrm{A}_{3}$ adenosine receptor, with the inhibition being lesser than that for knocking-down p53. This suggests that $A_{3}$ adenosine receptor in part mediates malignant pleural mesothelioma cell apoptosis by the mechanism independent of p53 upregulation.

In conclusion, the results of the present study show that for a main pathway extracellular adenosine is transported into cells and in turn, converted to AMP, which upregulates p53 expression to induce caspase-independent apoptosis in malignant pleural mesothelioma cells, and that for a branch pathway $\mathrm{A}_{3}$ adenosine receptor participates in adenosine-induced apoptosis in malignant pleural mesothelioma cells. The results also suggest that AMP converted from intracellularly transported adenosine promotes the p53 gene transcription, responsible for malignant pleural mesothelioma cell apoptosis.

\section{References}

1 Raja S, Murthy SC, Mason DP: Malignant pleural mesothelioma. Curr Oncol Rep 2011;13:259-264.

2 Saitoh M, Nagai K, Nakagawa K, Yamamura T, Yamamoto S, Nishizaki T: Adenosine induces apoptosis in the human lung cancer cells via an intrinsic pathway relevant to activation of AMP-activated protein kinase. Biochem Pharmacol 2004;67:2005-2011. 


\section{Cellular Physiology Cell Physiol Biochem 2012;30:61-74

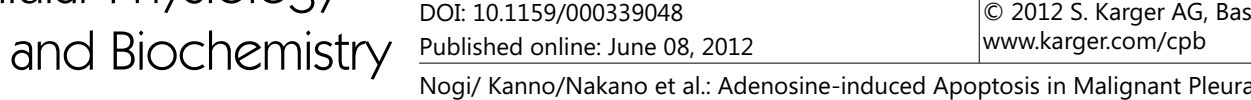 Nogi/ Kanno/Nakan
Mesothelioma Cells}

3 Yang D, Yaguchi T, Nakano T, Nishizaki T: Adenosine activates AMPK to phosphorylate Bcl- $\mathrm{X}_{\mathrm{L}}$ responsible for mitochondrial damage and DIABLO release in HuH-7 cells. Cell Physiol Biochem 2011;27:71-78.

4 Yang D, Yaguchi T, Yamamoto H, Nishizaki T: Intracellularly transported adenosine induces apoptosis in HuH-7 human hepatoma cells by downregulating c-FLIP expression causing caspase-3/-8 activation. Biochem Pharmacol 2007;73:1665-1675.

5 Yang D, Yaguchi T, Nakano T, Nishizaki T: Adenosine-induced caspase-3 activation by tuning Bcl- $\mathrm{X}_{\mathrm{L}} /$ DIABLO/IAP expression in HuH-7 human hepatoma cells. Cell Biol Toxicol 2010;26:319-330.

6 Tsuchiya A, Kanno T, Saito M, Miyoshi Y, Gotoh A, Nakano T, Nishizaki T: Intracellularly transported adenosine induces MCF-7 human breast cancer cells by accumulating AMID in the nucleus. Cancer Lett 2012; in press.

7 Yang D, Yaguchi T, Nagata T, Gotoh A, Dovat S, Song C, Nishizaki T: AMID mediates adenosine-induced caspase-independent HuH-7 cell apoptosis. Cell Physiol Biochem 2011;27:37-44.

8 Yang D, Yaguchi T, Lim CR, Ishizawa Y, Nakano T, Nishizaki T: Tuning of apoptosis-mediator gene transcription in HepG2 human hepatoma cells through an adenosine signal. Cancer Lett 2010;291:225229.

9 Saito M, Yaguchi T, Yasuda Y, Nakano T, Nishizaki T: Adenosine suppresses CW2 human colonic cancer growth by inducing apoptosis via $A_{1}$ adenosine receptors. Cancer Lett 2010;290:211-215.

10 Sai K, Yang D, Yamamoto H, Fujikawa H, Yamamoto S, Nagata T, Saito M, Yamamura T, Nishizaki T: A adenosine receptor signal and AMPK involving caspase-9/-3 activation are responsible for adenosineinduced RCR-1 astrocytoma cell death. Neurotoxicol 2006;27:458-467.

11 Yasuda Y, Saito M, Yamamura T, Yaguchi T, Nishizaki T: Extracellular adenosine induces apoptosis in Caco-2 human colonic cancer cells by activating caspase- $9 /-3$ via $\mathrm{A}_{2 \mathrm{a}}$ adenosine receptors. J Gastroenterol 2009;44:56-65.

12 Tamura K, Kanno T, Fujita Y, Gotoh A, Nakano T, Nishizaki T: $A_{2 a}$ adenosine receptor mediates HepG2 cell apoptosis by downregulating Bcl- $\mathrm{X}_{\mathrm{L}}$ expression and upregulating Bid expression. J Cell Biochem 2012; doi: $10.1002 / j \mathrm{jcb} .24048$.

13 Bar-Yehuda S, Stemmer SM, Madi L, Castel D, Ochaion A, Cohen S, Barer F, Zabutti A, Perez-Liz G, Del Valle L, Fishman P: The $\mathrm{A}_{3}$ adenosine receptor agonist CF102 induces apoptosis of hepatocellular carcinoma via de-regulation of the Wnt and NF- $\mathrm{KB}$ signal transduction pathways. Int J Oncol 2008;33:287-295.

14 Kim SJ, Min HY, Chung HJ, Park EJ, Hong JY, Kang YJ, Shin DH, Jeong LS, Lee SK: Inhibition of cell proliferation through cell cycle arrest and apoptosis by thio-Cl-IB-MECA, a novel $\mathrm{A}_{3}$ adenosine receptor agonist, in human lung cancer cells. Cancer Lett 2008;264:309-315.

15 Morello S, Sorrentino R, Porta A, Forte G, Popolo A, Petrella A, Pinto A: Cl-IB-MECA enhances TRAILinduced apoptosis via the modulation of NF- $\kappa B$ signalling pathway in thyroid cancer cells. J Cell Physiol 2009;221:378-386.

16 Panjehpour M, Karami-Tehrani F: Adenosine modulates cell growth in the human breast cancer cells via adenosine receptors. Oncol Res 2007;16:575-85.

17 Varani K, Maniero S, Vincenzi F, Targa M, Stefanelli A, Maniscalco P, Martini F, Tognon M, Borea PA: A receptors are overexpressed in pleura from patients with mesothelioma and reduce cell growth via Akt/ nuclear factor-кB pathway. Am J Respir Crit Care Med 2011;183:522-530.

18 Vanags DM, Pörn-Ares MI, Coppola S, Burgess DH, Orrenius S: Protease involvement in fodrin cleavage and phosphatidylserine exposure in apoptosis. J Biol Chem 1996;271:31075-31085.

19 Pietra G, Mortarini R, Parmiani G, Anichini A: Phases of apoptosis of melanoma cells, but not of normal melanocytes, differently affect maturation of myeloid dendritic cells. Cancer Res 2001;61:8218-8226.

20 Candé C, Cecconi F, Dessen P, Kroemer G: Apoptosis-inducing factor (AIF): key to the conserved caspaseindependent pathways of cell death? J Cell Sci 2002;115:4727-4734.

21 Daugas E, Susin SA, Zamzami N, Ferri KF, Irinopoulou T, Larochette N, Prévost MC, Leber B, Andrews D, Penninger J, Kroemer G: Mitochondrio-nuclear translocation of AIF in apoptosis and necrosis. FASEB J 2000;14:729-739.

22 Ye H, Cande C, Stephanou NC, Jiang S, Gurbuxani S, Larochette N, Daugas E, Garrido C, Kroemer G, Wu $\mathrm{H}$ : DNA binding is required for the apoptogenic action of apoptosis inducing factor. Nat Struct Biol 2002;9:680-684.

23 Bilyy R, Kit Y, Hellman U, Stoika R: AMID: new insights on its intracellular localization and expression at apoptosis. Apoptosis 2008;13:729-732. 
24 Li W, Sun L, Liang Q, Wang J, Mo W, Zhou B: Yeast AMID homologue Ndi1p displays respiration-restricted apoptotic activity and is involved in chronological aging. Mol Biol Cell 2006;17:1802-1811.

25 Marshall KR, Gong M, Wodke L, Lamb JH, Jones DJ, Farmer PB, Scrutton NS, Munro AW: The human apoptosis-inducing protein AMID is an oxidoreductase with a modified flavin cofactor and DNA binding activity. J Biol Chem 2005;280:30735-30740.

26 Ohiro Y, Garkavtsev I, Kobayashi S, Sreekumar KR, Nantz R, Higashikubo BT, Duffy SL, Higashikubo R, Usheva A, Gius D, Kley N, Horikoshi N: A novel p53-inducible apoptogenic gene, PRG3, encodes a homologue of the apoptosis-inducing factor (AIF). FEBS Lett 2002;524:163-171.

27 Varecha M, Amrichová J, Zimmermann M, Ulman V, Lukásová E, Kozubek M: Bioinformatic and image analyses of the cellular localization of the apoptotic proteins endonuclease G, AIF, and AMID during apoptosis in human cells. Apoptosis 2007;12:1155-1171.

28 Wu M, Xu LG, Li X, Zhai Z, Shu HB: AMID, an apoptosis-inducing factor-homologous mitochondrionassociated protein, induces caspase-independent apoptosis. J Biol Chem 2002;277:25617-25623.

29 Yaguchi T, Nakano T, Gotoh A, Nishizaki T: Adenosine promotes GATA-2-regulated p53 gene transcription to induce HepG2 cell apoptosis. Cell Physiol Biochem 2011;28:761-770. 